\title{
Structure, Agency and Museum Policies
}

\author{
Clive Gray* University of Warwick
}

\begin{abstract}
This paper reports on the results of recent empirical research on the interaction of structure and agency in the museums sector in England in the context of policy-making within individual museums and galleries. Policy in the museums sector is subject to a large number of political, economic, social and technological pressures and demands that are both externally and internally created: the management of these pressures and demands provides the opportunity for the establishment of multiple responses by the members of individual organizations. The effects of hierarchy, organizational and functional centrality, accountability and professionalism in this process, and the manner in which legitimacy and ideology are employed as central resources by museums staff, are identified. The focus on an under-researched issue allows for an original evaluation of claims and assumptions about what drives the policy choices that are made within museums.
\end{abstract}

Key Words: Museum policy, structure and agency, England

'Management is never easy, and managing a museum in the current environment can be especially challenging' (Davies et al., 2012, 345)

\section{Introduction}

Amongst the many truisms that exist in the museums sector is that there is a great deal of complexity involved in the making of policy within individual museums. In some cases the idea of 'complexity' is really nothing more than a general recognition that there is a lot of 'stuff' out there which affects organizational and actor behaviour, with museum staff being seen as subject to a large number of often contradictory demands from a large number of interested parties. These demands are located within particular sets of structural, behavioural and environmental characteristics which are assumed to have a range of independent effects on the processes of

policy choice. This paper investigates these ideas by developing an empirical analysis of the management of the complex organizational and behavioural environments that museums are located within through the use of a critical realist approach to the relationships of structure and agency in the making of policy choices within museums. The role of professional values, managerial and accountability requirements, external policy demands and the individual choices and understandings of museum staff members are examined to investigate how the complexities of policy-making within museums can be understood and explained.

\section{Structure and agency}

The idea that there is a complex set of relationships in place between individual actors and the contexts within which they are functioning is hardly original, even if understanding these relationships has given rise to numerous debates and a large number of approaches for their investigation (Gray 2014). In broad terms the approach adopted in this paper rests upon the critical realist position developed by Archer (1989; 1995; 2003), as modified by the norm circle arguments of Elder-Vass (2010a;Archer \& Elder-Vass 2012). This approach is directly applicable 
to the examination of complex policy systems as a consequence of the focus that it has on the dynamic interplay between individual, structural and systemic factors, thus combining the analysis of both holistic and sub-system features of policy systems (Archer 1995, 135-63; Fyfe 1996; Elder-Vass 2010b; Morcol 2012, 62-92). Archer's (2003; 2007) position on the relationships of structure and agency ${ }^{1}$ is effectively concerned with the interplay between reflexive individuals and the objective conditions within which they are functioning. While these conditions can produce both constraints on and opportunities for individual action, a key feature of them is that they are not absolute in their effects but are open to active management by those social actors who are located within their boundaries, with these actors adopting individually different approaches to precisely how conditions are understood and what can be done within them.

The current paper is concerned with how staff within publicly-funded museums in England manage the range of external and internal structural constraints and opportunities that confront them. It assumes that the techniques and practices that are used in individual museums derive from the understandings of, and priorities attached to, the significance and meaning of the structural contexts - such as governmental policies, financial capabilities, and professional norms and standards - within which museum staff operate. The existence of multiple pressures and demands within museums can lead to both ambiguous and self-contradictory expectations being placed upon organizational members, as well as straight-forward and coherently inter-connected ones. The management of the tensions that these generate can be understood as being played out through the underlying relationships between exogenous and endogenous limits and opportunities in individual museums, and the ability and willingness of staff to exercise choice in managing these. Thus the focus of analysis is on the inter-action between a range of structural variables, the precise exercise (or not) of individual agency, and the ways in which museum staff manage organizational complexity.

In this context the role of the structure-agency relationship is expected to be directly related to the actual policies and practices that are found within individual museums and galleries and thus provides a direct link between the relatively abstract ontological and epistemological concerns that Archer's position has developed from (Archer 1989; 1995) to the questions of everyday practice and understanding that it has led to (Archer 2003). While there are many general explanatory models of why organizational policies take the form that they do (see, for example, Sabatier 2007) most of these rely upon abstract assumptions about human behaviour, such as the claim that people employ forms of means-end rationality when deciding upon courses of action (Hindmoor 2006). The structure-agency concern with the reflexive understandings that actors employ in undertaking their roles adopts the very different position of seeing behaviour as something that needs to be accounted for in the particular rather than the abstract. The consequence of this is that the use of a structure-agency framework for analysis establishes a conscious concern with identifying the exact relationship between the contexts within which action and policy choice is taking place and how individual actors manage (or are managed by) these conditions.

\section{Structure, agency and museums}

The museums sector has certain characteristics that mark it out as different from other policy sectors:

- it is a small policy environment both in its own right and in comparison with other arenas of public policy, whether assessed in terms of amounts spent on it or the number of staff employed within it, and it has become a compactly self-contained policy arena that is capable of being made sense of in ways that larger policy environments (such as education or health) may not as a result of the more complicated inter-organizational and policy spill-over effects that are associated with these larger sectors. Even the pressures, in England, to widen the focus of the museums sector as a result of instrumentalizing pressures from central government have tended to depend upon the ways in which museums staff have reacted to these pressures rather than anything else (Gray 2008): in this instrumentalizing vein the museums sector has not been the main focus of central government policy but the mechanism through which non-museums policies are put into practice; 
- arising from this, the museums sector is not a politically-central subject for actors in the public sector in Britain ${ }^{2}$ - certainly concerns about the instrumentalization of museums were not related to how museums could, or should, affect the policies that were being undertaken in other policy sectors but with how these other sectors might affect the internal activities of museums. The consequence of this lack of centrality is that the sector has become subject to a form of 'normal' sectorally-specific politics that is largely unaffected by large levels of intervention by policy actors beyond those directly and centrally concerned with it, leading to the opportunity for people within the sector to operate according to their own policy concerns and commitments;

- it is, however, accepted as being something where state actors are expected to have a direct concern with its provision and organization, usually as a form of public good, meaning that it is tied in with expectations about the forms of accountability and public service that are a part of state activity, requiring some fit with more general policy expectations than those that specifically concern the sector;

- it contains well-developed professional networks of actors which are almost entirely independent of other such sets of actors, thus providing a relatively self-contained universe of core policy participants.

- The consequence of this is that the embeddedness of museums within a specific relatively isolated policy universe directly impinges on what occurs within it, providing the possibility of differentiating between endogenous and exogenous sources of pressure/demand upon policy choices in a fairly clear-cut fashion. This allows the identification of the role of sectoral actors/agents in interpreting, implementing and otherwise reacting to systemic and structural pressures. While groups of professional actors within the museums sector may well disagree with each other about what the exogenous demands that are placed upon them actually mean, and what the most appropriate response to these demands may be, their individual and collective responses to these demands can certainly be identified as examples of agency at work within the sector.

While the current paper deals with structure/agency in the museums policy sector in England these sectoral characteristics are not unusual in other countries. Even in cases where museums have a more central political role in public life, either in terms of creating ideas and images of 'the nation' or 'the community' or 'the people' (as shown in Knell et al. 2011, for example) that are then used for political purposes, such as the creation of the 'imagined community' of nationality and nationalism (Anderson 2006 [1983]), or as elements for the direct exercise of forms of cultural diplomacy (Nisbett 2013) and general international relations (Sylvester 2009), these uses of them are largely secondary and instrumental in comparison with more traditional forms of political activity within nation-states. Certainly direct state control of museum contents, displays and exhibitions is relatively rare: even in states with relatively low levels of direct democratic engagement governmental control tends towards the 'arm's-length' or is based on forms of self-censorship rather than on explicit direction (Verutti 2014). The consequence of this is that there is a cross-national tendency for the museums sector to be both politically non-central and, quite commonly, a semi-detached part of the overall political system, free to operate in its own way as long as this does not negatively impinge on the larger political and ideological expectations and requirements of national, regional and local governments (Gray 2015a). This does not mean that museums are actually politically unimportant in the grand scheme of things - a point emphasized by Message (2014: 23) - only that they are not generally treated as being so by national political actors. The consequence of this is that while on occasion museums and museum policy can become matters of political moment they are generally left to their own devices, allowing internal actors a freedom of action and room for manoeuvre that is not always to be found in other policy sectors. In this respect the status of the museums sector as a matter of 'low' politics - 'those residual matters which in normal circumstances could be left to governments and interests in the periphery' (Bulpitt 1983: 3) provides the means by which actors internal to the sector can stake a claim to effective policy control and autonomy. 
The research which forms the basis for this paper is based on 40 semi-structured interviews with staff employed in public sector museums within England: 16 in local authority museums and galleries (covering unitary, metropolitan district and district councils); three in national museums; 14 in Trust museums (where local authorities or Boards of Trustees own the collections but they are managed independently); and seven in University museums/ galleries. The interviews lasted between 35 minutes and two-and-a-half hours each. The division between types of museum rests on the hypothesis that organizational form will affect the ways in which policy is both managed within museums and galleries and how this will be affected by exogenous structural and systemic pressures. A further division hypothesized to be important lies in the functional and hierarchical differentiation of staff members, with differing professional expectations and pressures and levels of centrality to overall and operational policy decisions being expected to affect the relevance of exogenous variables. In total 23 'front-line' staff and 17 'managers' were interviewed: the 'front-line' staff were divided between 11 curators, 10 education/outreach officers, and two conservators. The managers, in turn, were divided between eight 'functional' managers (responsible for particular service areas - two curatorial, two conservation and four educational), and nine 'service' managers (concerned with the overall museums service that was offered). Half of the interviewees were located in single-site areas (individual museums [12] and galleries [eight]), and half were located in multiple sites, or had responsibility for cross-service and cross-locational activities. It is recognized that the interviewees do not form a statistically representative sample of public-sector museums or museum employees in England - with there being an over-representation of University and Trust museums and an under-representation of local authority and national museums, and an over-representation of education/outreach staff and an under-representation of conservation staff - so there is an element in the discussion of the findings that is indicative rather than anything more definitive.

While the distinctions between the staff who were interviewed were derived from hypotheses covering organizational form, professional function and hierarchical location, further hypotheses were involved in the analysis of the interview data itself. In total seven hypotheses were examined, with these operating at an individual, a locational, and a systemic ${ }^{3}$ level. These hypotheses detailed the different anticipated inter-relationships between sets of structure/ agency variables that would affect their relative impact on the overall patterns of policy activity that exist within the museums sector. Their examination, however, also requires a clarification of what, exactly, is meant by 'structure' in the context of the research.

In crude terms 'structures' refers to factors that affect the actions, choices and beliefs of individual actors and which cannot be reduced to the level of individual determination. A distinction can be drawn between endogenous (internally derived organizational) and exogenous (externally determined contextualizing) factors. The one exception to this lies in the case of power where its distribution and uses are assumed to have endemic and all-pervasive effects rather than simply being endogenously/exogenously determined, even if there are specific endogenous/exogenous dynamics associated with it. Structural factors are assumed to have differences in terms of their centrality to individual organizational settings and agent behaviour, giving rise to distinct sets of effects. At a macro-level the factors concern ideology, rationality and legitimacy; at the meso-level, externally-located political choices about policy priorities and preferences, how policy should be managed, policy ideas, the policy instruments that will be utilized (Howlett 2011: 41-59), and the formal and informal allocation of functions and organizations; at the micro-level, specific organizational policies and policy instruments, staff resources and expertise, and financial resources are included (see Gray 2012: 6-12 for a detailed discussion of these factors).

As the research is based upon qualitative interview data it is only dealing with the perceptions that staff have about the influences on their behaviour, and the open-ended nature of the interview process did not involve a detailed examination of pre-ordained categories of potential influence, relying instead on the identification of categories of opportunity and constraint by staff themselves. The consequence of this is that it is not possible to be definite about whether these influences did have an actual effect in terms of practical policy consequences (which could only be determined by an examination of policy outputs), or in terms of specific museum practices (which would require an ethnographic approach to be employed: Macdonald 
2002; Bouquet 2012). As the concern, however, is with how staff managed the multiple pressures and demands that they perceived as affecting both the limits to their choices and their opportunities for policy determination and innovation, this does not form a barrier to the identification of the complexity of the policy environments within which they operated, or how this complexity was actually managed. By developing from the perceptions of staff the identification of common patterns of influence, strategic choice and management can serve to establish whether such commonality is related to particular sets of behavioural and structural factors rather than to others. These can then be used to account for how the policy process is managed within museums.

\section{Structures, agents, factors and hypotheses}

Rather than simply report on the findings generated from the research interviews in terms of each of the hypotheses, the following discussion is couched in terms of the inter-relationships between structural factors and agency in the context of these hypotheses ${ }^{4}$. In this way the dynamic nature of the relationships between factors and their specific contributions to multiple sets of causal linkages can be identified. This, in turn, can demonstrate whether there are single or simple sets of effects and consequences that the factors give rise to at the systemic level, and whether the reality of policy choice is dealt with in multiple ways across a variety of organizational locations as a consequence of the concatenation of circumstances that exist in any given case.

In terms of the macro-level variables of ideology, rationality and legitimation there is no doubt that these have a significant and enduring effect upon how policy pressures are understood and managed by museum staff. The professional and functional backgrounds of staff have a direct impact on how sense is made of the environmental context within which they are operating, with 15 of the 40 interviewees referring directly to professional 'standards', 'specialisms', 'judgements', 'autonomy', 'knowledge', 'skills' and 'values' as the basis upon which their policy decisions are based. Of remaining staff, 12 made explicit reference to 'the collection' as the key to understanding museum/gallery policy - and this is generally understood as being a form of shorthand for referring to the particular museological ideology that can be found in the ICOM definition of museums (ICOM 2013), with this, in turn, being closely related to views of professionalism within the sector ${ }^{5}$. Another 10 museum staff members made reference to specific internal, functional policies (ranging across policies for exhibition, audience development, access, knowledge provision, and human remains, amongst others) as being central, with seven of these being, probably not surprisingly, functional specialists rather than general managers, and of the three managers who specifically referred to this, two were managers of functional specialisms within their own services. Thus, in total, 37 out of 40 of the staff interviewed made conscious reference to sets of ideas that were either professionally or functionally-based, with these being closely and clearly associated with their individual roles and positions within their museums. The prevalence of these underlying bases to how staff understood their own activities and choices indicates that somewhat traditional ideas based on functional and professional status affect the basis upon which decisions are made in the publicly-funded museums services of England. And these have yet to be replaced by the newer models of public and modernizing management, based upon generic management principles, that have been developed since the mid-1980s, or, indeed by the 'new museology' principles that developed from the 1960s onwards (McCall \& Gray 2014).

However, alongside this museums-centred set of ideological views was a more general belief that museums were important for societies in ways that did extend into the terrain of the 'new museology' and emphasized the educational, social and community roles of museums. This perspective was commonly held across organizations, specialisms and hierarchical locations and was used as a mechanism to reinforce the centrality of professional and functional values. The emphasis upon an internally-derived perception of forms of ideological effect should not be taken, however, to mean that staff do not recognize the importance of the external pressures that ideology can give rise to. There is certainly a recognition that museums are 'in a constant state of justification' (District Council, Service manager) to ensure their survival ${ }^{6}$, with this necessitating 'ticking the council's boxes' (District Council, Service manager), and 
doing 'what you have to do to get your Grant-in-Aid' (National, Conservation manager), with this leading to a position where 'you give us the money and we'll jump through your hoops' (Unitary, Service manager). In these cases it might be thought that museum staff are adopting a simple instrumental relationship to the demands that are generated by ideologically-driven external policy requirements, with these being hurdles to be negotiated and managed rather than direct determinants of internal choice. Certainly some staff operate in this fashion saying, in reference to national government policy, that 'you change the language but you still do the same stuff' (Trust, Education manager) indicating a clear distinction between external demands and internal actions (also see McCall 2009; 2010 on this point).

A distinction can be drawn in terms of who museum staff see themselves as being accountable to - whether in terms, for example, of line-management or financial or elected political accountability - with implications for ideas of legitimacy within the system. Whom it is that accountability is owed to will affect how the demands of other actors within the system will be responded to. In this respect the general position is that central government actors 'are not particularly interested' in museums as 'their minds are elsewhere' (Trust, Service manager) and therefore had limited impact on day-to-day museum operations (Trust, Conservator), and that there is 'no real national museums strategy' (Unitary Council, Service manager) anyway, and that the effect of Arts Council England (ACE), which now acts as the distributor of central government money to a range of museum services, tends only to be felt at 'stratospherically high' levels within them, and has minimal direct effect on most staff (Trust, Education manager). In these cases the lack of direct accountability to these external organizations results in a lack of perceived importance for the demands that they make in terms of the everyday activities of museum staff.

In specific museums, however, the picture is somewhat different. In these cases direct accountability is largely towards non-national groups of actors (Boards of Trustees, local councillors and University Councils/Boards of Governors) with central roles to play in affecting museum operations, rather than towards external organizations and actors with limited direct, practical, impact. While 'professional values tend to over-ride those of the employing authority when they differ' (Metropolitan District, Education manager) there is a much greater acceptance of the legitimacy of those to whom accountability is directly owed to make policy decisions that have to be abided by. This was strongly expressed in local authority museums where party political control had shifted after local elections, with this leading to both policy changes and changes in service support and management style, with a firm expectation that museums needed to toe the party line. Local councillors were seen as particularly important in this respect, with individual councillors being recognized as vital for the generation of support inside the machinery of the local authority, as without this there would be an increased vulnerability for museums services, particularly in the conditions of financial constraint that have existed in recent years.

A consequence of the significance that is attached to accountability has been an acceptance of the importance of the general organization-wide policies and expectations that exist in local authorities, in particular, in affecting museum service policy ${ }^{7}$. In this case the need to fulfil the requirements of various local authority plans, strategies and policies (to contribute to regeneration (Metropolitan District, Curator), for example), was specifically mentioned by all 16 of the local government respondents - even when it was often pointed out that some of these policies required considerable re-interpretation to ensure that they fitted in with the particular circumstances of the museums services involved, indicating an exercise of agency to manage these demands. In a similar vein, six of the seven University interviewees referred to the importance of overall University policies and expectations for the specific policies that their museums and galleries pursued, particularly with regard to widening engagement with the University's collections for both external audiences (including other museum services) and staff and students within the Universities themselves. In the case of Trusts, eight out of 14 respondents mentioned Trust strategies and policies as being important, with three singling out the targets that were set for the service as being particularly important - even if there is a tendency for these to 'go up regardless of staffing and resources' (Trust, Education).

The effect of these accountability concerns is felt at the level of legitimacy rather than in terms of matters of ideology. As such, the professional and functional ideologies of staff are 
tempered by the clear recognition that other, non-museum, actors have a valid role to play in establishing the policy context within which professionals can undertake their functions. Professional values and practices can also serve to defend the autonomy of museum staff to manage the demands that are made upon them by external actors, and as long as the requirements of these external actors are seen to be met then a degree of independence can be preserved: one museums service being effectively left alone because 'we're seen not to have screwed up yet' (District Council, Service manager). To this extent the picture becomes more complicated: there is clearly a policy concern here (rather than simply a legitimacy one) but the extent to which this policy effect is simply a matter of managerial competence rather than anything else, is open to question - a detailed examination of the content of organizational policies would be needed to answer it. Again, however, the current focus is on staff perceptions so the question is simply being raised in this instance.

The second set of factors to consider are the externally-generated, meso-level, ones, with these covering more than simply the specific policies that national governments may have concerning museums and museums services, being more concerned with the policy contexts that national governments establish for the management of public policy as a whole. Given that central government has minimal direct control over the functioning of any of the museums - including the nationals - that exist within England, this contextualization function is the closest that it gets to affecting museums policy: even under the Labour governments of 1997-2010 the array of Funding Agreements that were reached with national museums only served to provide extremely broad-brush outlines of policy expectations that allowed the centre no direct role in policy implementation and which created policy ambiguities (Gray 2015b) that handed control of practice to the museums themselves.

The first of the meso-level variables - national government policy priorities and preferences - is one that might be expected to have an obvious effect on day-to-day policy in public sector museums through the centrality of expenditure constraint to both the coalition government of 2010-15 and the current Conservative government's economic policies. The Museums Association (MA), the major professional body representing museums and museum staff in the United Kingdom (UK), has produced three survey reports (Newman \& Tourle 2011; Evans 2012, 2013) on the impact of recent cuts in public expenditure on museums and, while there are exceptions, the general picture is of consistent and, in some cases, large-scale reductions in museum expenditure across the UK, with over $50 \%$ of museum services reporting budget cuts in each of the first two years, and $49 \%$ in the third. It is hardly surprising, then, that funding and budget cuts were seen as major issues for the majority of interviewees. In most cases questions of finance were seen as being largely concerned with the local working-out of national decisions in which a 'strong streak of opportunism' (Trust, Education manager) is made use of to manage the consequences of these meso-level decisions. Little of this management was concerned with changed expectations in terms of income generation (mentioned specifically by only three respondents), but much more of it was expressed in terms of the impact of reduced (and reducing budgets) on staff resources and time. A persistently expressed view was that museums were something of 'a Cinderella service' and 'nobody wants to give you the money' (University, Service manager) as they were not central to the concerns of the larger organizations with which they were associated, leading to a persistent need to justify their existence, and encouraging the development of advocacy arguments in the absence of persuasive evidence (Belfiore 2009). The consequence of this was that there was a good deal of pressure inside museums to find the means to demonstrate their relevance in terms of the policy preferences of funding agencies. In this respect either an active instrumentalization or 'attachment' of policy to other areas (Belfiore 2012; Gray 2002, 2008) had become a defensive strategy adopted within the sector, rather than being something that was consciously imposed by external actors. This was particularly evident in the case of the education function of museums where the major determinant of what was to be provided to school-children was determined by the contribution that the museums service could make to meeting the demands of the national curriculum ${ }^{8}$. Longer-serving museums staff, however, indicated that defensive instrumentalism had always been a tool for managing external policy demands 'particularly when there's money attached to it' (District Council, Service manager). Shifts in the focus of internal museum policies from 
dealing with matters of social inclusion ('always where the money was') to those of mental health ('it's where the money is', Metropolitan District, Education manager) demonstrate the manner in which a filtering exercise takes place that is not concerned with the specifics of external policy detail but is more concerned with organizational and functional survival. In this respect meso-level demands become something to manage to the benefit of the museum itself rather than inescapable pressures that must be conformed to.

It is largely accepted amongst the interviewees that the impact of larger-scale preferences for managing public policy has been much diluted with the advent of nationallevel coalition government, even though some of the preferences introduced by the previous Labour governments are still seen to be important. In particular, an emphasis on the provision of evidence of policy impact is seen to be significant for generating support amongst those to whom museum staff are accountable, something which serves to reinforce the tendencies towards policy instrumentalization that have been generated by funding pressures. A similar picture can be seen with the manner in which the macro-policies (such as social inclusion under the Labour governments of 1997-2010) of central government are played out. It is noticeable that the Conservative Party's 'Big Society' idea was never explicitly referred to by interviewees (while social inclusion was often referred to as an influence on the justification for policy developments within individual organizations) unless prompted ${ }^{9}$ and then the views expressed about it were hardly supportive - 'nobody can afford it and nobody can be bothered' (Unitary, Curator), 'I have never seen it clearly articulated as to what it means' (Trust, Service manager). This may well be a consequence of the shift from single-party to coalition government leading to a lack of clear central direction and so not too much should be made of this point except to indicate that, as might be expected, policy legacies persist even after governments change, and declared policy desires do not always turn into direct policy effects. Whether the recent return to single-party government in the United Kingdom will lead to the development of a more activist role for central government and the Department which has overall responsibility for English museums, the Department for Culture, Media and Sport (DCMS), is currently not known but, on the interview evidence, the ability of the centre to impose itself on the museums sector would appear to depend upon how staff in individual museums manage the demands of the centre as much as it depends upon what the centre is demanding.

It is also evident that there is a strong effect generated by the location of staff inside organizational hierarchies. While both 'front-line', direct service delivery, and managerial, behind the scenes, staff make reference to similar sets of influences on their policy choices, with a very strong functional dimension to this (so both learning officers and education service managers almost always make frequent reference to the importance of the national curriculum for what they do, and conservators and conservation managers always refer to the British Standards and the Portable Antiquities Scheme requirements that apply to their work), there is a clear view amongst most of the 'front-line' staff that their senior general and functional managers will, and do, act as a form of buffer to absorb and mediate the demands that are made by external actors and organizations, thus clearing the way for the exercise of professional judgement over the day-to-day issues that are involved in matters of direct service delivery. 'Front-line' staff are well aware of the external political and policy demands and pressures that exist - not least as these mean that 'I spend a lot of time doing council crap' (Metropolitan District, Curator) - but the meaning of these in terms of their practical work is not central. With managers, the requirements for close contact with those to whom accountability is owed serves to broaden the perspective of policy relevance - even if this is only as a result of the hierarchical links that they have with more senior levels of management inside their own organization. This is particularly marked in the case of local authority staff, where museum services are not only a discretionary service but are also seen as a relatively unimportant one in terms of contributing to the overall objectives of the local authorities concerned. This leads to the position where not only are services 'run on a shoe-string' (District, Education Officer), and the museum service is 'in a constant state of justification' (District, Service Manager), but also where 'we're constrained by lots of policies from constrained areas but... the policy sometimes gets in the way of doing the job' (Metropolitan District, Education Manager): external policy can thus be seen as being understood to have adverse effects for internal practice.

Exogenous policy influences, however, are not simply restricted to those generated 
at the national or organizational level - European and wider international policies, treaties, conventions and standards have an effect on the sector, as do the standards of professional practice that are supported by the International Council of Museums (ICOM) (see Ambrose \& Paine 2012), and which underpin the requirements for museum accreditation within the United Kingdom. The specific impact of these more wide-ranging - and far-reaching - influences, covering everything from the Washington Conference Principles on Nazi-Confiscated Art to the SPECTRUM standards for museum documentation, is hard to identify as it is 'largely second nature' (Unitary, Curator) for museums professionals to have regard to them. The lack of explicit discussion of these supra-national influences could be taken to be simply a reflection of how far they have been incorporated into the professionalized perspective that museum staff have developed, which has transformed them from an exogenous into an endogenous source of policy influence. At the very least this indicates that an attempt to draw a clear boundary between the nature of structural constraints and opportunities as being either strictly endogenous or exogenous is likely to be difficult to establish in any absolute sense, as the nature of agency intercedes between structural variables and everyday organizational practice. This means that the translation of structural influences through the exercise of agency can change how these influences are understood and managed. Thus what may appear to be an exogenous influence to an outsider can become an endogenous influence to those who are actually making the system work.

The allocation of functions and responsibilities by governments is expected to have an effect through demarcating the control of both policy implementation and formal policy making. The importance attached by museum staff to where accountability lies is reinforced by the patterns of organizational and functional distribution that are present within the overall policy system and this then extends to incorporate control of policy practice, and the dynamics of the relationship between the museums sector and the wider governmental policy environment. In effect there is a form of organizational hierarchical differentiation in play whereby organizational form affects patterns of accountability which, in turn, affect the perceived and actual room for manoeuvre that staff will have in terms of managing their policy environments. This was particularly marked in the case of the Trusts where the perceived constraints on action that existed under previous organizational arrangements (largely associated with local authorities) were expected to be replaced by shorter chains of decision-making, independence of financial choice (largely tied to access to different sources of finance than those available to local authorities), and freedom for the exercise of professional judgement. It should be noted, however, that most of the Trusts involved had only recently adopted that organizational form and so these views were usually in the shape of expectations rather than established fact. In practice the new Trusts are constructed as management arrangements rather than being completely independent organizations in their own right, and the manner in which they function cannot be divorced from the demands and requirements of their parent organizations. The effect of this on museum practice has yet to be fully examined.

What is clear in terms of these organizational arrangements is that central government is in an extremely weak position - even when dealing with the national museums - concerning policy implementation and control. The default position is one where there is very little capability for the centre to influence what precisely occurs across the range of publicly-funded museums or within them, thus leaving the exercise of agency to other actors within the system (West \& Smith 2005). Indeed the most commonly identified direct roles for central government departments were the provision of advice (specifically mentioned were human remains, licensing of firearms collections, and the operation of the Portable Antiquities Scheme), or the establishment of broad policy preferences that museums could attach themselves to for funding purposes or the gaining of political support to justify their decisions. For these a number of government departments had a practical effect for museums/museum services: not only was the DCMS mentioned, but so also were the Departments for Children, Families and Schools, Business, Innovation and Skills, and the Home Office. To put this into context though, it should be noted that the most commonly mentioned national organization was the Higher Education Funding Council for England (HEFCE), which was referred to by every single one of the University museums. This was usually in terms of the direct and indirect funding that it provided to universities in general - and some museums/galleries in particular - but also to how it could be used as a 
justificatory device for the making of particular internal policy decisions.

In terms of policy instruments it is not the particular instruments that exist in their own right which matter, but the manner in which their exercise is controlled and made use of by actors. This has a clear relationship to the ideas of resource dependency proposed by Rhodes (1981): instruments are not simply, from this perspective, used directively in a top-down fashion but are, instead, subject to matters of unequal resource distribution and negotiated settlements for their effect. In the case of museums the balance of informational instruments rests heavily - but not entirely - with individual museums and museum services, as does the control of technical instruments. Financial instruments, on the other hand, are largely controlled outside of the museum sector itself by a range of funding organizations, including central government departments, quangos and local authorities. Regardless of the precise detail of these arrangements the manner in which instruments are utilized has important implications for how the complexities of the policy environment will be both made sense of and managed by system participants, with this being affected by unequal access to necessary resources.

At the micro-level of individual museums/galleries/museum services the structural frameworks that are in place for their management are clearly understood to be examples of spaces for negotiation and arenas for the exercise of agency rather than as entities that exercise a role that is independent of individuals, even if their impact is greater than that which can be exercised by individuals alone, a clear example of the emergent nature of these frameworks (Elder-Vass 2010b). While reference was made in individual cases to the importance of organizational re-structurings for the manner in which institutional policies were made, this was couched in the context of the role of particular individuals (usually new heads of museum services but occasionally in the context of changes in political control of local authorities, or changes in the lead councillor for the service) rather than being seen as the strategic outcome of policy or service reviews. The creation of new Trust arrangements - which might be thought to provide the opportunity for large-scale reviews - was usually couched in the language of creating room for manoeuvre and opportunities to manage services independently of mesolevel structural constraints rather than in terms of allowing such reviews. In general, however, there were differences at the level of individual services and museums as to how this affected practice: in some cases the person at the top 'makes a huge difference' (Trust, Head of Service), while in others the practicalities of management involve 'endless discussions with other people' leading to 'many conflicts of interest and on your time' (Trust, Curator) indicating the importance of team-working and the involvement of 'external stake-holders' (University, Collections Manager) to museum functioning, rather than the role of the individual per se. In addition the functional and hierarchical divisions between staff members had the effect of mediating the role of individuals qua individuals, particularly in the light of the importance that was attached to professional values as a core under-pinning of policy decisions and choices.

The importance of the specifics of individual cases for understanding the broader pattern of the relationship of structure and agency in museums/museum services is reinforced if a closer examination is undertaken of one of the key assumed policy influences - functional differentiation - in the context of micro-level structural factors. In this respect there are clear differences in perception about the importance for policy choice of different functional groups. A common criticism of how museums function, particularly in the 'new museology' (McCall \& Gray 2014) has always been the dominance of 'the curator' in terms of the internal pecking order that exists within the sector, and the non-curatorial interviewees were commonly in accord that this significance was still in place in many institutions. However, it is worth noting that one curator (National) referred to their role as being a combination of 'the keeper of the knowledge' and a 'fact monkey', depending upon what role they were fulfilling and which audience they were dealing with. This indicates that curators do not necessarily see themselves as being in an exalted position in the museum hierarchy but are instead fulfilling multiple roles that affect their centrality and general importance. The perceived importance of the curator for other interviewees, however, extended beyond general professional values - the importance of 'the collection' (which could be seen as a necessary explanation for the status of curators given that it is expected to be the focus of their work), for example, was seen as central for explaining the work of museums staff across all functional groups in all types of museums. In that way it appears to be as much a matter of engrained expectations of curatorial centrality 
as it is a factual statement. Discussions of team-working and the inter-relationships between functional categories within individual museums often indicated that the reality was much more complicated than this simple hierarchical view of functional significance would assume, with many examples of staff co-ordination and inter-action in the making of exhibitions and displays and in the direct provision of functional specialisms being evident. In a similar fashion the importance of the managerial tier as a buffer between the demands of exogenous agents and structures and the exercise of endogenous agency only captures a part of the complexity of the managerial role that is undertaken. Managers do have a clear role to play in the downward mediation of exogenous demands and pressures but they also usually have to manage a variety of specific functional demands, as well as the upward mediation of endogenous pressures and demands arising from the deliverers of services, as well as undertaking their own role in the construction of organizational policies. In other words, museum staff at all levels perform multiple functions within their organizations, with these roles being as much a consequence of the internal management structures that exist as they are to do with professional specialization.

\section{Conclusions}

As can be seen, there is a complex web of intersecting expectations, demands and pressures in operation within the museums sector in England, and the relationship of these to general organizational characteristics of functional and hierarchical differentiation, professional status, organizational form and patterns of accountability indicates that similar patterns of response could be anticipated in other political systems. The manner in which a variety of structural features are managed by - and manage - the participants within the system serves to provide a set of contexts within which policy choices are made and demonstrates the inter-play of structure and agency in these processes. If nothing else it demonstrates that the exact pattern of operations within individual museums and entire museum systems is not a matter of the simple dominance of either structural constraints or free agency but the outcome of the interplay between policy management, policy pressures and policy understandings.

The analysis of complexity through the lenses that are provided by ideas derived from structure and agency provides a way of making sense of the relationships of systems, individual agents and interaction that exist within museums. In structure/agency analysis generalizability is a necessity for the explanation of the specific inter-relationships between the complex behavioural and structural phenomena that give shape to the overall policy systems that exist within individual museums, and it is the understanding of these inter-relationships that then allows for the making of generalizations from the specific example to the overall systemic level, and vice-versa. The current application of structure and agency to the English museums sector confirms the complex nature of the interplay between organizational structures, professional values, patterns of accountability, and the individual choices that staff within museums make, to produce a picture of policy complexity that allows for the identification of the sources of dynamism in the organizational life of museums.

Received $14^{\text {th }}$ January 2015 Finally Accepted $14^{\text {th }}$ June 2015

\section{Acknowledgements}

This paper was supported by a British Academy Grant (SG 111848). Thanks to all of the museum staff who allowed me to interview them. Thanks also to Vikki McCall and Andrew Newman for their comments on an earlier version of this paper that was presented at the Annual Conference of the Political Studies Association of the United Kingdom, Manchester, April 2014. Thanks as well to the anonymous reviewers of the submitted paper whose comments have been extremely helpful in encouraging me to clarify the arguments of this paper. Responsibility for the contents of the paper rests with the author. 


\section{Notes}

1 Determining what counts as 'structure' and what as 'agency' is a complex issue and has been the subject of much debate with no definitive distinction having been reached as yet (Gray, 2014). Archer $(2007,37-8)$ sees the issue as being as much a matter of 'relationality' as anything else: the difference being between causal powers that are reducible to individual actors ('agency') and those which are not ('structures') - such as, in her example, the effects of decentralization and centralization on the operations of educational systems with neither term being simply a matter of human attribution.

2 With the exception of occasional arguments about the Parthenon Sculptures (Elgin Marbles) as the actor George Clooney has recently found.

3 With these concerning the relationship of: individual staff members to internal organizational structures; museums/museum services to external organizational environments; and organizations/individuals to overall policy environments. Full details of the hypotheses that were employed in the analysis, as well as the justifications for their use, are available from the author.

4 Dealing with each hypothesis in turn would serve to confuse the manner in which individual and sets of factors have multiple effects across a number of hypotheses, and as it is these factors, and how they are managed, that are the main foci of the research a concentration on them is seen as preferable.

5 And this being subject to criticism from the 1940s onwards following the publication of reports in the United States and the United Kingdom that were significant for the development of a new community focus for museum work: Bourke (2011: 274).

6 This is particularly the case in local authorities, where museums are a discretionary rather than a statutory service.

7 This is not to claim that local authorities, or any other organizations, are capable of exercising agency over the staff in museums, only that the staff within them produce documents, policies, strategies and so on that operate as forms of structural constraint for museum staff. In this respect references to organizations (and values) should be read as references to the collective output that is produced by the actors who inhabit these organizations rather than to a singular actor known as, for example, 'the local authority'.

8 The extent to which this will continue given the changes to the national school curriculum that are currently in train, and the consequent effect of this on education services within museums and galleries, are both open questions at the moment.

9 This happened in five cases as a direct development of what was being said by the interviewee, usually about the social inclusion agenda.

\section{References}

Ambrose, T. \& C. Paine (2012) Museum Basics, $3^{\text {rd }}$ ed, Abingdon: Routledge.

Anderson, B. (2006 [1983]) Imagined Communities: Reflections on the Origin and Spread of Nationalism, Revised Edition, London: Verso.

Archer, M. (1989) Culture and Agency, Cambridge: Cambridge University Press.

(1995) Realist Social Theory: The Morphogenetic Approach, Cambridge: Cambridge University Press. 
(2003) Structure, Agency and the Internal Conversation: Cambridge, Cambridge University Press.

(2007) 'The Trajectory of the Morphogenetic Approach', Sociológica, Problemas e Practicas, 54, 35-45

Archer, M. \& D. Elder-Vass (2012), 'Cultural Systems or Norm Circles? An Exchange', European Journal of Social Theory, 15, 93-115

Belfiore, E. (2009) 'On Bullshit in Cultural Policy Practice and Research: Notes From the British Case', International Journal of Cultural Policy, 15, 343-59

(2012) '“Defensive Instrumentalism” and the Legacy of New Labour's Cultural Policies', Cultural Trends, 21, 103-11

Bouquet, M. (2012) Museums: A Visual Anthropology, London: Berg.

Bourke, M. (2011) The Story of Irish Museums1790-2000: Culture, Identity and Education, Cork: Cork University Press.

Bulpitt, J. (1983) Territory and Power in the United Kingdom: An Interpretation Manchester: Manchester University Press.

Davies, S. R. Paton \& T. O’Sullivan (2012) 'The Museum Values Framework: A Framework for Understanding Organizational Culture in Museums', Museum Management and Curatorship, 28, 345-61

Elder-Vass, D. (2010a) The Causal Power of Social Structures: Emergence, Structure and Agency, Cambridge: Cambridge University Press.

(2010b) 'For Emergence: Refining Archer's Account of Social Structure', 59-78 in W. Olsen (Ed.), Realist Methodology Vol. 1, Los Angeles, Sage.

Evans, G. (2012) The Impact of Cuts on UK Museums: July 2012 (London, Museums Association http://www.museumsassociation.org/campaigns/funding-cuts/cutssurvey, accessed $27^{\text {th }}$ May, 2015

(2013) Cuts Survey 2013 (London, Museums Association http://www.museumsassociation. org/campaigns/funding-cuts/cuts-survey, accessed 27 May, 2015

Fyfe, G. (1996) 'A Trojan Horse at the Tate: Theorizing the Museum as Agency and Structure', 203-28 in S. Macdonald \& G. Fyfe (eds), Theorizing Museums, Oxford: Blackwell.

Gray, C. (2002) 'Local Government and the Arts', Local Government Studies, 28 (1), 77-90.

(2008) 'Instrumental Policies: Causes, Consequences, Museums and Galleries', Cultural Trends, 17, 209-22

(2012) Museums Policy: Structural Invariants and Political Agency? (Paper to the International Centre for Cultural and Heritage Studies, Newcastle University: http:// www2.warwick.ac.uk/fac/arts/theatre_s/cp/staff/gray/research/, accessed 27 May, 2015

(2014) '"Cabined, Cribbed, Confined, Bound in" or "We are not a Government Poodle": Structure and Agency in Museums and Galleries', Public Policy and Administration, 29, 185-203

(2015a) The Politics of Museums, Basingstoke, Palgrave Macmillan. 
(2015b) 'Ambiguity and Cultural Policy', The Nordic Journal of Cultural Policy, 18, $61-75$

Hindmoor, A. (2006) Rational Choice, Basingstoke: Palgrave Macmillan.

Howlett, M. (2011) Designing Public Policies: Principles and Instruments, London, Routledge.

ICOM (2013),Museum Definition, http://icom.museum/the-vision/museum-definition, accessed 25 February, 2015

Knell, S. P. Aronsson, A. Amundsen, A. Barnes, S. Burch, J. Carter, V. Gosselin, S. Hughes \& A. Kirwan (eds), (2011) National Museums: New Studies From Around the World, Abingdon: Routledge.

Macdonald, S. (2002) Behind the Scenes at the Science Museum, Oxford: Berg.

McCall, V. (2009) 'Social Policy and Cultural Services: A Study of Scottish Borders Museums as Implementers of Social Inclusion', Social Policy and Society, 8, 319-31

(2010) 'Cultural Services and Social Policy: Exploring Policy-Makers' Perceptions of Culture and Social Inclusion', Journal of Poverty and Social Justice, 18, 169-83

McCall, V. \& C. Gray (2014) 'Museum Policies and the New Museology: Theory, Practice and Organisational Change', Museum Management and Curatorship, 29, 19-35

Message, K. (2014) Museums and Social Activism: Engaged Protest, Abingdon: Routledge.

Morcol, G. (2012) A Complexity Theory for Public Policy, Abingdon: Routledge.

Newman, K. \& P. Tourle (2011), The Impact of Cuts on UK Museums, London: Museums Association: http://www.museumsassociation.org/campaigns/funding-cuts/cutssurvey, accessed 27 May, 2015

Nisbett, M. (2013) 'Protection, Survival and Growth: An Analysis of International Policy Documents', International Journal of Cultural Policy, 19, 84-102

Rhodes, R. (1981) Control and Power in Central-Local Government Relations, Aldershot: Gower.

Sabatier, P. (Ed.) (2007) Theories of the Policy Process, Boulder: Westview Press.

Sylvester, C. (2009) Art/Museums: International Relations Where We Least Expect It, Boulder: Paradigm.

Verutti, M. (2014) Museums in China: The Politics of Representation after Mao, Woodbridge: Boydell.

West, C. \& C. Smith (2005) "'We are not a Government Poodle": Museums and Social Inclusion under New Labour', International journal of Cultural Policy, 11, 275-88. 
${ }^{*}$ Clive Gray is Associate Professor in Cultural Policy Studies at the University of Warwick. His research covers cultural policy in general; ontology, epistemology and methodology in cultural policy analysis; and policies and policy-making in the museums sector. He has published widely on all three and is the author of The Politics of Museums (Palgrave Macmillan 2015).

\section{Address:}

Centre for Cultural Policy Studies,

University of Warwick,

Millburn House,

Coventry CV4 7HS.

Email: C.J.Gray@Warwick.ac.uk 